\title{
THE BRAZILIAN 'ECOLOGICAL-ICMS': A PES SCHEME BASED ON DISTRIBUTION OF TAX REVENUE ${ }^{1}$
}

Matheus Linck Bassani

\begin{abstract}
PHd Candidate and Master in International Law at Federal University of Rio Grande do Sul-UFRGS, Brazil. Postgraduated in Tax Law Specialization Course, at Instituto Brasileiro de Estudos Tributários - IBET. Visiting researcher of the Center for Energy, Petroleum and Mineral Law and Policy - CEPMLP, at University of Dundee, UK. Member of the Environmental Law Comission of OAB/RS. Attorney of Law. matheusbassani@hotmail.com
\end{abstract}

\begin{abstract}
The scope of this legal brief is to analyze the Brazilian legislation concerning the 'Ecological-ICMS', the 'ecological' State value-added tax imposed on the circulation of goods and services ICMS. Using a deductive method, it was identified this tax mechanism operates as a type of 'payment for ecosystem services' (PES) scheme in practice, offering the possibility to stimulate environmental protection by distributing revenue from ICMS collected by States to Municipalities that promote conservation of ecosystems and biodiversity. This type of measure was motivated by the need to address challenges in providing economic compensation for Municipalities that undertook environmental protection measures in Brazil, and can serve as a form of positive incentive for the conservation and sustainable use of biodiversity.
\end{abstract}

Keywords: Convention on Biological Diversity (CBD) - Ecological-ICMS Distribution of revenue - Qualitative and quantitative criteria - PES scheme

1 This publication is based in part on copyright protected material (Material) belonging to the International Development Law Organization (IDLO) and is not necessarily a full or accurate reflection of the Material. IDLO has granted a license to the author for the reproduction and adaptation of the Material for academic and non-commercial purposes, otherwise all rights are reserved by IDLO in respect of the Material. The views expressed are the views of the author and do not necessarily reflect the views or policies of IDLO or its Member Parties. 


\section{BACKGROUND}

\subsection{The status of biodiversity in Brazil}

Brazil is a country with rich biodiversity and vast forest areas. Nonetheless, as many developed and developing countries, Brazilian biodiversity has been vanishing, and to implement legal measures to cease negative actions and promote the positive ones is a challenging task. In this regard, providing economic incentives that address the underlying causes of biodiversity loss is part of this challenge.

Historically, deforestation has been one of the greatest environmental problems in Brazil, not just by eliminating biodiversity, but also as the major cause of greenhouse gas emission. The creation of conservation units as well the promotion of a PES Scheme, like the Ecological ICMS (the 'Ecological' Value Added Tax on the Circulation of Goods and Interstate and Intermunicipal Transportation and Communication Services), has the scope to cease environmental degradation, and also intends to restore those already degraded, by providing an economic incentive to Municipalities that undertake conservation measures in their territory.

\subsection{The legal history of this legal measure}

Some Municipalities that undertake environmental protection measures have considered themselves to be in an economically disadvantaged position by having part (or most) of its territory restricted due to its use for public water supply, even to neighboring Municipalities, or for the creation of conservation units. Municipalities in the Brazilian State of Paraná have been the catalysts for change, mobilizing the creation of the Ecological-ICMS, which emerged as a way to compensate those Municipalities deprived of the use of their lands for conservation purposes. ${ }^{2}$ As an example, the Municipalities of Piraquara, Campo Magro and São José dos Pinhais, in the State of Paraná, are in the top 10 national rank revenue receivers from Ecological-ICMS.

\subsection{The Brazilian legal system}

Tax law deals with the study of taxation, from the creation of a tax or levy to the collection of the tax revenue or to the moment when

2THENATURECONSERVANCY.EcologicalICMS:historyandperspectives.Availableat:http:// www.icmsecologico.org.br/index.php?option=com_content\&view=article\&id=74\&Itemid=77. Access in 28/02/2014. 
the obligation to pay the tax ceases to exist, either by its payment or by an extinctive cause of the tax credit. The distribution of tax revenues, however, is not the object of tax law, but rather of financial law and eventually administrative law. ${ }^{3}$ Given that the legal system must be analyzed and interpreted in a coherent way, it is important to consider these two branches of law (Financial Law and Tax Law) by different principles and legal instruments, regardless of their theoretical and didactic divisions. ${ }^{4}$

The Brazilian Constitution is founded by democratic republican principles, with executive, legislative and judiciary powers, constituted by 3 government spheres: Union (federal entity), States and Municipalities (local governments). The Union is the only entity that can create tax competences, through the Constitution, but each sphere has its own competence to charge different taxes. Part of the tax revenue received by the State is redistributed to Municipalities according legal criteria. In this regard, the distribution of tax revenue to promote environmental goals is considered as one type of possible positive incentives, which has in fact been implemented in Brazil since the beginning of the 1990's, as will be analyzed in this case study. The Ecological-ICMS does not change the distribution of tax competences, since it does not influence on the power of the federal government to introduce and charge their own taxes, but merely the distribution of tax revenues by States. ${ }^{5}$ This brief background aims to present that the Ecological-ICMS is considered part of Financial Law, asserting criteria of distribution of the revenues by States.

In Brazil, the Federal Constitution regulates the allocation of tax revenues under articles 157 to 162, in Section VI, Chapter I, Title VI (related to the national tax system). In addition, articles 157 to 162 of the Constitution regulate the relationship between the Municipalities, States and the Union, and not between the government and the taxpayer. This means that it is only possible to dispose about distribution of tax revenues after it has been collected by the competent political entity. The competence to institute and charge ICMS rests solely and exclusively to the States, pursuant to article 155, II, of the Constitution. On average, revenue arising from ICMS collection represents $90 \%$ of total tax revenues, constituting one of the most important sources of State's income. This means that States depend substantially on revenue from ICMS to provide services and fulfill obligations such as maintenance of

3 CARRAZZA, Roque Antonio. Curso de direito constitucional tributário. $14^{\mathrm{a}}$ edição, rev. ampl. e atual. São Paulo: Malheiros, 2000. p. 445.

4 CARVAlHO, Paulo de Barros. Curso de direito tributário. $18^{\mathrm{a}}$ ed. rev. atual. São Paulo: Saraiva, 2007. p. 18.

5 MORAES, Alexandre de. Constituição do Brasil interpretada e legislação constitucional. 7. ed. atual. até a EC n55/07. São Paulo: Atlas, 2007. p. 1938. 
public facilities, salary payments, investments, etc.

Article 158, IV, of the Constitution states that twenty five percent of ICMS revenue belongs to Municipalities; article 158 states that revenue assigned to Municipalities, referred to in subparagraph IV, will be credited according to the following criteria:

(I) - three fourths $(3 / 4)$, at least, in the proportion of value added in transactions involving the movement of goods and the services rendered held in their territory;

(II) - up to one fourth (1/4), according to State law provisions or, in the case of the territories (rarely applied), federal law.

Therefore, it can be inferred that one-sixteenth (1/16) of all State ICMS revenue may be transferred to Municipalities according to discretionary criteria of State law. State governments have been using this provision as the legal basis to create means to promote environmental protection, such as the Ecological-ICMS, which represents a special way to distribute ICMS revenue to Municipalities. Therefore, the next step is to evaluate the criteria used by States to transfer portion of revenue from the ICMS to certain Municipalities, according to their degree of development of environmental sustainability.

It is important to stress that this measure does not mean the creation of a new tax, and that the duty of taxpayers to pay the tax is not connected to environmental protection as for example, polluting, deforestation, etc. The Ecological-ICMS is a form of allocation of revenues from the collection of the tax according to criteria established in State law as a way to encourage environmental protection, as envisioned in article 158, IV, of the Brazilian Federal Constitution, and later on regulated by specific State law. It can be characterized as a legal and effective instrument to allocate the tax revenue to Municipalities to perform environmental sustainability, maintenance and/or recovery of degraded areas of environmental preservation or degradation phase. ${ }^{6}$

It should be noted that Municipalities must fulfill the legal requirements to receive the share of Ecological-ICMS by the States, but do not have the duty to invest the amount received from EcologicalICMS in environmental preservation related activities. Municipalities are free are free to apply the resources in any areas, stimulating investments in infrastructure, health, education and also environment protection.

The Ecological-ICMS aims to compensate the cost of the opportunity of the soil exploration by the distribution of tax revenue to Municipalities which contribute for the environment preservation, ensuring a positive externality. ${ }^{7}$ An advantage is that this mechanism

6 BRITTO NETO, José Gomes de. A utilização do ICMS ecológico como um instrumento de política pública para a manutenção do meio ambiente sustentável. Revista da Escola Superior da Magistratura de Sergipe, n. 6, 2004, p. 89-100.

7 ALTMAN, A. Pagamento por serviços ambientais: aspectos jurídicos para a sua 
does not affect directly the market, neither competition, as would be the case of the creation of a new green taxes leading to additional tax charges.

However, despite the positive incentives, the main challenge to implement the Ecological-ICMS is considered to check and control if the Municipalities are really fulfilling the requirements of the State Law to receive revenue according to the criteria established. This is cited by the States as an excuse to not implement such measures, stating the lack of budget for supervision. ${ }^{8}$

In other words, it is possible to affirm the omission of the State on acting in favor of environmental protection, without assuming proper conduct as stated by article 225 of the Brazilian Federal Constitution. On the case of Rio Grande do Sul State, effectively, there is a financial crisis with high public debt affecting investments on infrastructure, health and education. Nonetheless, other States, like Minas Gerais and Paraná, are also debtors ${ }^{9}$ and implemented the measure properly, concluding that no excuse must be accepted for the omission on adopting the Ecological-ICMS.

\section{ELEMENTS OF THE LEGAL MEASURE}

The key players for the implementation and effectiveness of the Ecological-ICMS are the States and Municipalities. The State Congress and the State Executive power must be engaged to approve the State Law adopting legal criteria for the distribution of tax revenue. After approving the law, the State Environment Ministry (in Brazil, called the State Environment Secretary) will be the supervising agent to determine which Municipalities are fulfilling the requirements and are thus entitled to receive the allocation of the respective revenue. Municipalities are the core of the Ecological-ICMS mechanism. They are the most interested entity on this system because they are recipients of revenue, and must be the mobilizers (pressure agents) for the approval of State Law. In addition, in order to actually receive the tax revenue, Municipalities need to provide evidence to be effectively protecting the environment, fulfilling all the criteria established in the State Law. The next section will analyze the specific legislation enacted by three different Brazilian States concerning the implementation of Ecological-ICMS, based on the Constitutional provisions outlined above.

aplicação no Brasil. p. 1.

8 This is the opinion of the Government of the State of Rio Grande do Sul, when the author and State's Representative have met in 2012.

9 BANCO CENTRAL DO BRASIL. Endividamento de Estados e Municípios. Available at: http://www4.bcb.gov.br/fis/dividas/lmdividas.asp. Access in: 19/03/2014. 


\subsection{The case of the state of Paraná}

The first State that implemented Ecological-ICMS was Paraná in 1991. This was facilitated by the fact that the Parana State Constitution provides under article 132, special treatment in the distribution of the share of ICMS revenue to Municipalities that have in their territory the following types of areas: i) protected areas, or that are directly influenced by them; and, ii) water sources for public supply. Given that this State was pioneer in adopting this type revenue-sharing technique, it will be the main focus of the analysis undertaken in this paper. Article 132 of the Constitution of Paraná was later on regulated by Complementary Law (CL) n. 59/91, and Executive Decree n. 974/91, providing that 5\% of the total percentage that Municipalities were entitled to receive from ICMS revenue would be distributed based on the following criteria:

(i) $50 \%$ to Municipalities with environmental conservation units;

(ii) $50 \%$ to Municipalities with water sources for public supply. Article 2, of the CL n. 59/91, states that Municipalities which fulfill both criteria will benefit from greater financial compensation. ${ }^{10}$

The Ecological-ICMS legislation in the state of Paraná aims:

(i) to increase the quantity and the area of protected areas (conservation units) and other specially protected areas (quantitative dimension);

(ii) to regulate planning, implementation and pursuit of sustainability of conservation units (qualitative dimension );

(iii) to encourage the creation of ecological corridors, connecting vegetation fragments;

(iv) the adoption, development and institution building, both at the State and Municipal levels, with biodiversity conservation;

(v) pursuit of tax justice for environmental conservation. ${ }^{11}$

In the case of item "iv", it means the possibility of creation of a relationship between the State's and Municipality's Environmental Secretariats. It is not necessary to create a specific institution for the implementation of Ecological-ICMS, but to coordinate between the payer and the beneficiary. Paraná uses a public institution named IAP - Paraná Environmental Institution for inspection and control of the

10 ZEOLA, Senise Freire Chacha. ICMS - instrumento de proteção e conservação do meio ambiente. Revista de Direito e Política, v. 8., jan-mar/2006, p. 55-78. p. 60.

11 W. LOUREIRO, ICMS Ecológico: a consolidação de uma experiência brasileira de incentivo a Conservação da Biodiversidade (1997) Available at: <http://ambientes.ambientebrasil. com.br/unidades_de_conservacao/artigos_ucs/icms_ecologico_-_a_consolidacao_de_uma experiencia_brasileira_de_incentivo_a_conservacao_da_biodiversidade.html $>$ Access on: 07/03/2009. 
revenues to be distributed to the Municipalities. About the item " $v$ ", it means that environment protection must be considered on the effective distribution of the revenue by the State, according the criteria of the State Law. The Ecological-ICMS is a mean to distribute the revenues respecting the environment, considered a collective right by the Brazilian legal system.

Any Municipality in Paraná State can benefit from EcologicalICMS resources, through the creation of conservation units, or increase of the surface area of conservation units already created by the Municipality itself or by another federal entity, or also by improving the quality of the conservation units, or other specially protected areas. To facilitate the exercise of the Ecological-ICMS, the percentage rates set for each Municipality is calculated through a specific formula that measures the 'Biodiversity Conservation Coefficient - BCC'. With regard to the conservation units, the process works from an evaluation of the quality of the conservation unit, which will result in the determination of a score. This score, if positive, represents a financial increase to the Municipality. ${ }^{12}$

Therefore, to receive the apportioned tax revenue, some criteria are considered for calculation purposes, provided by the Ordinance n. 134/97, of the Environmental Institute of Paraná - IAP. It has been called Management Category and Conservation Factor, with the following scores: Ecological Stations (between 0.8 and 1.0); Biological Reserves (between 0.8 and 1.0); Parks (between 0.7 and 0.9); Federal, State or Municipal Forests (0.64); Relevant Ecological Interest Area (0.66); Environmental Protection Area (0.08); Indigenous Lands Area (0.45) and Special Areas of Regulated Use (0.30). ${ }^{13}$ Conservation units at all levels should be evaluated under the quantitative and qualitative aspects, each year, and new ones must be registered on the State Register of Conservation Units, to determine the transfer of revenue to Municipalities. ${ }^{14}$

It should be noted that the Ecological-ICMS has proven to be effective in the State of Paraná. Between 1992 and 2000, there was an increase of $1.894,94 \%$ on the surface of Municipal conservation units; of $681,03 \%$ in State conservation units; of $30,50 \%$ in Federal conservation units and indigenous lands, and 100\% on State Private Natural Heritage Reserve (PNHR). There was also an improvement in

12 BRAZIL. Paraná State Conservation Units Scores. Available at: <http://www.uc.pr.gov.br/ modules/conteudo/conteudo.php?conteudo=56>. Access in: 17/03/2009. See also BRAZIL. Decree n. 2791/Paraná - 27/12/1996, for precise informations, due to the complex arithmetic formula.

13 CAMPOS, L. P. R. ICMS Ecológico: experiências nos Estados do Paraná, São Paulo e Minas Gerais e alternativas na Amazônia. Apud ZEOLA, op. cit., p. 62.

14 ZEOLA, op. cit., p. 62. 
the quality of preservation of Municipal, State and PNHR parks. ${ }^{15}$ In addition, the adoption of this measure accounted for significant increase in the revenue received by some Municipalities, mitigating, to some extent, the reduction of productive activity in their territory due to the existence of conservation units. For instance, in the Metropolitan area of Curitiba, capital of Paraná, there were significant discussions about the burden of the Municipalities that have significant portions of their territories inserted in watersheds for regional supply and, therefore, have limitations in land use. The city of Piraquara was one of the most benefited with increased revenue amounting to $99 \%{ }^{16}$

Thus, the experience with Ecological-ICMS in Paraná has not only been pioneer but has also proven to have functioned as a positive incentive to maintain different forms of conservation areas and to protect watersheds, providing increased financial support to Municipalities that undertake these activities. In the section below, the experiences of other states in the implementation will be briefly analyzed. Despite not being as significant as the experience of Paraná, making a comparative analysis with the experiences of other States can provide important insights on the functioning and challenges of this type of measure.

\subsection{The experiences of other states}

The Law of the States of São Paulo, Minas Gerais and Rio Grande do Sul will be analyzed, considering the importance of these States in the Brazilian scenario. Other States that also adopted this system to encourage environmental protection include Santa Catarina, Mato Grosso, Mato Grosso do Sul, Pernambuco, Rondônia, Pará and Amapá.

2.2.1) The State of São Paulo was the second to adopt the Ecological-ICMS, through Law n. 8.510 in 1993. It established that a percentage of $0,5 \%$ of the tax revenue from the ICMS should be allocated to Municipalities with protected areas, and other $0,5 \%$ to Municipalities with water reservoirs for the generation of electricity. In relation to conservation units, the legislation provides benefits to Municipalities with territories integrating conservation units created by the State, excluding the areas created and managed by other federal entities. The legislation also envisions management categories to generate

15 LOUREIRO, Wilson. ICMS Ecológico: a consolidação de uma experiência brasileira de incentivo a Conservação da Biodiversidade. Disponível em: $<\mathrm{http}: / /$ www.ambientebrasil.com. br/composer.php3?base $=. /$ snuc/index.html\&conteudo $=. /$ snuc/artigos $/$ icms.html.$>$ Acesso em $\underline{07 / 03 / 2014 .}$

16 C. HARDT, et al. (2008) Gestão metropolitana: relação com a população e com a qualidade hídrica. ABEP <http://www.abep.nepo.unicamp.br/encontro2008/ docsPDF/ABEP2008_1735.pdf $>$ at 01/02/2014. 
benefits, excluding the Private Natural Heritage Reserves (PNHR). However, the law of São Paulo has not adopted the qualitative criteria of conservation, which would allow better use of the mechanism in favor of the consolidation of conservation units, as happens in Paraná. ${ }^{17}$

In São Paulo, the calculation of the index (for revenue distribution) is responsibility of the Secretariat of Environment and its publication is made by the State Treasury. The calculation takes into account environmental and social factors of each Municipality and each protected area. Social factors are also considered for calculating the percentage of revenue, such as the population size, the value added and tax revenues of the Municipality. Among environmental factors, the area of the conservation units and the size of the areas occupied considering the restriction of use of these spaces are considered.

The amount of revenue distributed has been higher year after year, as informed by the Secretariat of Environment of the State of São Paulo ${ }^{18}$ :

$$
\begin{aligned}
& \text { - } 2010 \text { - R\$ 92.071.487,84; } \\
& \text { - } 2011 \text { - R\$ 101.338.415,02; } \\
& \text { - } 2012 \text { - R\$ 108.041.161,07; } \\
& \text { - } 2013 \text { - R\$ 123.035.805,85. }
\end{aligned}
$$

This increase in the amount of Ecological-ICMS distributed shows the increased concern of the Municipalities to fulfill the criteria of the State Law, which is the basis for the calculation of the distribution of the revenue.

2.2.2) The State of Minas Gerais adopted the Ecological-ICMS through Law n. 12.040 of 1995, also called the Robin Hood Act. Such legislation put in place, in addition to the criteria of the conservation units (protected areas) and watersheds for public supply, environmental sanitation, collection and disposal of garbage and historical heritage as possibilities of allocation of revenue to Municipalities under this initiative. ${ }^{19}$

17 LOUREIRO, Wilson. ICMS Ecológico: a consolidação de uma experiência brasileira de incentivo a Conservação da Biodiversidade. Disponível em: $<$ http://www.ambientebrasil.com. br/composer.php3?base=./snuc/index.html\&conteudo=./snuc/artigos/icms.html.> Acesso em 07/03/2014.

18 SECRETARIA DO MEIO AMBENTE DO ESTADO DE SÃO PAULO. ICMS Ecológico. Available at: http://www.ambiente.sp.gov.br/cpla/icms-ecologico/. Access in 19/03/2014. 19 BRAZIL. Law n. 12.040 of 1995 (State of Minas Gerais). Article 1 - The share of revenue from tax collection (...) will be distributed in the percentages and periods indicated in Annex I of this Law, according to the following criteria: (...);

VIII - Environment: considering the following: A) the portion of a maximum of $50 \%$ (fifty 
The method used in Minas Gerais is similar to that adopted in Paraná, but differs by inserting, beyond the criteria of conservation and public watershed, supply and sewage waste treatment, with concern for environmental sanitation. ${ }^{20}$ However, The State of Minas Gerais did not adopt qualitative variables for the calculation of indices that Municipalities are entitled to receive, thereby not providing an incentive to use more effectively the Ecological-ICMS benefit for the consolidation of conservation units.

Comparing the situation of Minas Gerais Municipalities before and after insertion of the Ecological-ICMS, there seems to be also a positive impact. Studies showed an increase in the percentage of tax revenue distribution, and in the number of Municipalities receiving ICMS transfers. However, studies also pointed out the need to consider the quality factor as a tool of evaluation of the composition of conservation, through the use of qualitative criteria. ${ }^{21}$ In addition, the area of conservation units was increased by slightly over 1 million hectares in five years (1996 to 2000), a 62\% increase. However, the EcologicalICMS is not considered the only reason for this increase in the number of conservation units, which can also be attributed to efforts by Municipalities to recognize existing units that had not been regulated by the State. ${ }^{22}$

\subsection{3) The State of Rio Grande do Sul established Ecological- ICMS through Law n. 11.038 in 1997, amended by Law n. 12.907}

percent) of the total will be distributed to Municipalities whose systems of treatment or final disposal of garbage and sewage, licensed with the State environmental agency operation, meet at least, respectively, $70 \%$ (seventy percent) and $50 \%$ ( fifty percent) of the population, and the maximum value to be assigned to each Municipality shall not exceed the relevant investment, estimated based on the population served and average cost "per capita" prescribed by the State Board of Environmental Policy, of the landfill, waste composting plant and wastewater treatment station systems;

B) the remaining funds will be distributed based on the Municipal Conservation Index , calculated in accordance with Annex IV of this Act, considering the State, Federal and Private conservation units as well as the Municipal units that may be registered, observed the parameters and procedures defined by the State environmental agency; ( ... ). Free translation by the author. 20 TREMEL, Rosângela; PEREIRA, Patrick da Luz. ICMS ecológico: a materialização do princípio do protetor-recebedor, Revista Jurídica Consulex, Brasília, n. 198, abril/2005, p. 49-51. 21 ARANTES, V. A. et al., Analysis of the ecological ICMS in Minas Gerais State by the political cycle perspective (2013) 13, 1, Revista de C. Humanas, p. 121-136. Available at: http://www.cch.ufv.br/revista/pdfs/vol13/artigo8vol13-1.pdf. Access in: 01/03/2014.

22 LOUREIRO, Wilson et. al., The Ecological Value-Added Tax: Municipal Responses in Parana and Minas Gerais, Brazil. Available at: http://www.icmsecologico.org.br/images/ artigos/a024.pdf Access in: 01/03/2014. 
in 2008. The allocation of revenue from ICMS according to the following percentages: "Article 1 - The rate of participation of each Municipality in the share of $25 \%$ of the revenue (...) will be obtained according to the following criteria:

(...) III - $7 \%$ based on the ratio between the area of the Municipality, multiplying by three (3) the environmental conservation areas, indigenous lands areas and those flooded by dams, except in the hydropower areas located on the Municipalities, calculated on the last day of the calendar year referred the investigation, reported in square kilometers, by the Division of Geography and Cartography of the Secretariat of Agriculture, Livestock and Agribusiness; (Amended by Law No. 12.907/08)".

Thus, this State did not establish an objective criteria, adopted by the States of Minas Gerais and Paraná, because the distribution was limited to the area of the Municipality in relation to the area preserved. This demonstrates the absence of a qualitative variable and a limited legislation related to the details to fulfill the requirements.

The impact of the Ecological-ICMS in Rio Grande do Sul is not transparent and the government has published no reports to date. In addition, there is a challenge regarding the lack of knowledge by the Municipalities of the measure, due to lack of political will of the State to encourage the fulfillment of the criteria. Rio Grande do Sul does not differentiate the Ecological-ICMS from the total revenue distribution. ${ }^{2324}$

\section{LESSONS LEARNED AND REMAINING CHALLENGES IN ACHIEVING THE TARGET}

According to article $158 \S$, II, of the Brazilian Federal Constitution, States have the power to legislate concerning the allocation of $1 / 4$ of the

23 THE NATURE CONSERVANCY. Available at: http://www.icmsecologico.org.br/index. php?option $=$ com_content $\&$ view $=$ article\&id=79\&Itemid=77. Access on: 12/02/2014.

24 In July 2012, the author of this article proposed to the Government of the State of Rio Grande do Sul, on a meeting with the Secretary of Development, in the State Administrative Office in Porto Alegre, RS, to amend the legislation, to implement a legal text that would make the criteria more qualitative and effective for the promotion of a sustainable environment. However, the attempt remains frustrated by the apparent lack of interest of the current Government in this subject. 
$25 \%$ of ICMS revenue, and to stipulate criteria for the allocation of this revenue. Some States have drawn up this prerogative and passed State legislation creating certain criteria that encourage Municipalities to adopt environmental protection measures. The Ecological-ICMS is not a tax imposed by States, as one might interpret, but only a way of sharing revenue to the Municipalities.

Despite not being able to solve immediately all national environmental problems, the Ecological-ICMS is a measure found by the States to promote environmental development in a sustainable manner. As can be concluded by the analysis of this brief, the Ecological-ICMS is a positive incentive to encourage environmental protection, but its effectiveness depends on:

i) adequate State Law;

ii) use of quantitative and qualitative criteria to determine the allocation of funds to Municipalities;

iii) strengthen the process of regularization, planning, implementation and maintenance of conservation units, sanitation and consequently, improving the quality of the environment and the life of society, reaching the main focus of Aichi Target 3.

iv) awareness of Municipalities about the incentive, in order to fulfill the criteria and apply for the benefit;

v) political will.

The Ecological-ICMS can be characterized by a positive incentive, but, despite its positive effects for environmental conservation, it is probably not sufficient to reduce the most active and broadly deforestation, pollution, etc., considering the great extension of Brazilian area. The area upon which Ecological-ICMS can be exercised must be extended in order to achieve a broader protection. In practice, in Paraná and Minas Gerais States (The States of Parana and Minas Gerais), the results had been very positive. In Paraná, the results achieved are more significant, as a result of the more sophisticated model of Ecological-ICMS implemented in that State, which imposed better qualitative criteria. In Paraná, it is reported Ecological ICMS raised the number of conservation units, improving the environment preservation: from 1992 to 2000, there was an increase of $1894,94 \%$ in surface units of Municipal conservation, $681,03 \%$ in State conservation units, 30,50\% in Federal protected areas and Indian lands.

As noted, the States do not maintain uniformity in the criteria adopted in State Law, when they encourage environmental protection. Qualitative and quantitative criteria, especially the former, should be included in the elaboration and adoption of these Laws. The more precise and specific legislation is the more benefits it can provide. The more and better criteria, more qualified is the legislation, providing the 
possibility of better allocation of efforts to promote the environment protection.

Political will is also a challenge for the establishment and implementation of the measure, as it depends on the executive State power to take the initiative for the proposal of legislation and its approval by the State congress. In addition, Municipalities also play a key role, firstly by exercising political pressure for States to adopt criteria for Ecological-ICMS. In addition, they must fulfill the criteria of the law in order to be able to benefit from allocation of tax revenues, and the more they comply, the more revenue they will receive. However, they have no legal obligation to use the revenue received specifically for the protection of the environment directly. Municipalities are free to use these resources for other public services such as education, health and infrastructure.

This lack of binding spending obligation is positive for the Municipalities, which depends mostly of the revenue to keep the public services, including environment protection. On the other hand, in Municipalities with other sources of revenues, the revenue arising from the Ecological-ICMS might be just a complement, and could be used for environmental purposes. This spending obligation could be directed to Municipalities with good social and economic conditions, or not dependent of the Ecological-ICMS only.

There is strong public participation on the implementation and effectiveness of the Ecological-ICMS, in the approval of the State Law, and the inspection of the criteria fulfillments to the distribution of the revenue. Basically, the public sector is the great engine of the measure. The conservation units are created by the Municipalities, with prior public consultation, in order to support the definition of the location, the size and the most appropriate boundaries for the unit (Article 5, Federal Decree n. 4.340/2002). ${ }^{25}$

An important issue is the high variation of the effects of the Ecological-ICMS due to the value added generated by a particular area of land. If the value added and primary production per hectare have low average levels, the conservation option seems more attractive in terms of ICMS revenue. For certain Municipalities in Minas Gerais would be financially attractive to create protected areas. For others, the motivation for setting aside land for protection would have to come from other factors, meaning that is more economic advantageous not to keep protected areas. ${ }^{26}$ Thus, the design of the tax allocation criteria

25 BRAZIL. Federal Decree n ${ }^{\circ}$ 4.340/2002. Available at: http://www.planalto.gov.br/ccivil_03/ decreto/2002/D4340.htm. Access on: 19/03/2014.

26 GRAN, M. G. Fiscal Incentives for Biodiversity Conservation: The ICMS Ecológico in Brazil. Available at: https://www.cbd.int/financial/fiscalenviron/brazil-fiscalicms-iied.pdf. Access in: 30/03/2014. p. 31. 
is very important in order to make conservation a more economically advantageous option and should be done with caution.

Finally, it has been pointed out that a large portion of Municipalities are not aware about the Ecological-ICMS ${ }^{27}$, showing a lack of dissemination about this incentive measure. This can be considered a great challenge for the effectiveness of the mechanism.

\section{KEY LESSONS LEARNED}

The Ecological-ICMS can represent a positive incentive, as a mechanism that provides distribution of tax revenue and works as a form of PES scheme in practice. It is implemented through Brazilian State Law, characterized by the transfer of tax revenue from States to local governments (Municipalities) in reward for measures to promote biodiversity conservation and sustainable use, such as the establishment of protected areas, protection and maintenance of watershed and other conservation activities.

This type of measure can be effective in protecting intergenerational rights to a healthy environment and exhaustible natural resources, consistent and in harmony with the $\mathrm{CBD}$, taking into account national socio economic conditions. This mechanism is an economic incentive for Municipalities to promote the environment protection. It is innovative as it provides additional funding specific for environmental protection, without creating new taxes or financial burden on tax payers, allowing for States to incentivize Municipalities to undertake conservation efforts.

Resuming:

- The Ecological-ICMS is an incentive that can stimulate local governments (Municipalities) to take measures to promote biodiversity conservation and sustainable use, consistent and in harmony with the $\mathrm{CBD}$, taking into account national socio economic conditions. It provides financial support to Municipalities that undertake conservation activities, without creating additional financial burden to tax payers.

- The Ecological-ICMS is not a green tax, but a type of a PES scheme based on distribution of tax revenue. This mechanism is based on the Federal Constitution and State law, and part of the mechanism of tax revenue distribution by the States to Municipalities. This type of incentive depends on adequate

27 UHLMANN, V. O.; ROSSATO, M. V.; PFITSCHER, E. D., Conhecimento dos gestores públicos sobre o instrumento de política pública ICMS ecológico nos municípios da quarta colônia de imigração italiana do RS, Enfoque: Reflexão Contábil UEM - Paraná, n. 29, v. 2, 2010, p. 83-102. Available at: http://periodicos.uem.br/ojs/index.php/Enfoque/article/ view/11396/6236. Access in 01/03/2014. 
State legislation containing both quantitative and qualitative criteria, and on enforcement and monitoring of the fulfillment of such criteria.

- Initiatives of different States in Brazil show a positive response to this legal measure, leading to substantive increase both in the number of protected areas and other types of conservation measures, and on tax revenue received by Municipalities.

- To achieve effective implementation of Ecological-ICMS, it is necessary not only to focus on the approval of the necessary legal framework, but also on implementation and capacity building of the State's Environmental Agency and the Municipalities.

- For better implementation, a case-by-case analysis must be undertaken to evaluate whether the incentive will be effective. A badly conceived mechanism might make it more economically advantageous to convert the area for other purposes, generating value, instead of keeping it protected.

- Political will is a challenge for the implementation of this measure, which relies on the State Government to introduce the legislation project, and to support its approval by the State legislative power. Municipalities might be the pressure agent to force State's governments to implement the Ecological-ICMS.

\section{Conclusion}

The distribution of tax revenue, prescribed in the Brazilian Federal Constitution, is the basis of this measure. Among the Brazilian States that have Ecological ICMS schemes, Paraná and Minas Gerais are considered to have the most advanced legislation, including both qualitative and quantitative criteria determining the terms of distribution of tax revenue for Municipalities. Considering the experience of these and other States in Brazil, as São Paulo e Rio Grande do Sul, the adoption and implementation of this type of measure, with adequate legislation, could represent an important contribution to the achievement of the goals of Aichi Target 3, generating new ways of financing biodiversity conservation and sustainable use without creating new taxes and financial burden on taxpayers.

The Ecological-ICMS can be a positive measure to promote the conservation of the environment. However, this mechanism faces a great challenge of implementation, which must be analyzed case by case. States without positive incentives measures need to approve an entire Ecological-ICMS legal system. Other States with an already ongoing system must improve State Laws to qualify the positive measures. 


\section{REFERENCES}

HARDT, C. et al. Gestão metropolitana: relação com a população e com a qualidade hídrica. ABEP. 2008. Available at: <http://www. abep.nepo.unicamp.br/encontro2008/docsPDF/ABEP2008_1735.pdf> Access in 01/02/2014.

ALTMAN, A. Pagamento por serviços ambientais: aspectos jurídicos para a sua aplicação no Brasil.

AMARAL, Paulo Henrique do. Direito tributário ambiental. São Paulo: Editora Revista dos Tribunais, 2007.

ATALIBA, Geraldo. Hipótese de incidência tributária. $6^{\mathrm{a}}$ ed. $8^{\mathrm{a}}$ tiragem. São Paulo: Malheiros, 2006.

ARANTES, V. A. et al., Analysis of the ecological ICMS in Minas Gerais State by the political cycle perspective (2013) 13, 1, Revista de C. Humanas, p. 121-136. Available at: http://www.cch.ufv.br/revista/ pdfs/vol13/artigo8vol13-1.pdf. Access in: 01/03/2014.

ÀVILA, Humberto. Teoria dos princípios: da definição à aplicação dos princípios jurídicos. $6^{\mathrm{a}}$ ed. São Paulo: Maleiros, 1998.

AZEVEDO, Plauto Faraco de. Ecocivilização: ambiente e direito no limiar da vida. $2^{\mathrm{a}}$ ed. rev., atual. e ampl. São Paulo: Editora Revista dos Tribunais, 2008.

BANCO CENTRAL DO BRASIL. Available at: http://www4.bcb.gov. br/fis/dividas/lmdividas.asp. Access in: 19/03/2014.

BRAZIL. Law n. 8.510/1993. (São Paulo State, Brazil). Altera a Lei 3.201, de 23 de dezembro de 1981, que dispõe sobre a parcela, pertencentes aos municípios, do produto da arrecadação do ICMS. Diário Oficial do Estado de São Paulo, São Paulo, 1993.

BRAZIL. Law n. 11.038/1997 (Rio Grande do Sul State, Brazil). Disponível em http://www.mp.rs.gov.br/ambiente/legislacao/id493. htm. Acessado em 13/02/2014.

BRAZIL. Law n. 12.040/1995. (Minas Gerais State, Brazil). Dispõe sobre a distribuição da parcela de receita do produto da arrecadação do ICMS pertencente aos Municípios, de que trata o inciso II do parágrafo único do artigo 158 da Constituição Federal, e dá outras providências. Diário Oficial do Estado de Minas Gerais, Belo Horizonte, 1995.

BRAZIL. Federal Decree $n^{\circ} 4.340 / 2002$. Available at: http://www. planalto.gov.br/ccivil_03/decreto/2002/D4340.htm. Access on 19/03/2014.

BRAZIL. Paraná State Complementary Law n. 59/1991. Dispõe sobre 
a repartição de 5\% do ICMS, que alude o art.2. ${ }^{\circ}$ da Lei n. ${ }^{\circ}$ 9491/90, aos municípios com mananciais de abastecimento e unidades de conservação ambiental, assim como adota outras providências. Diário Oficial do Estado do Paraná, Curitiba, 1991.

BRAZIL. Paraná State Decree n. 2791/1996. Define critérios técnicos a que alude o art. 5. ${ }^{\circ}$ da Lei Complementar n. ${ }^{\circ} 59$, de 01 de outubro de 1991. Diário Oficial do Estado do Paraná, Curitiba, 1997.

BRAZIL. Paraná State Conservation Units Scores. Available on: $<$ http:// wWw.uc.pr.gov.br/modules/conteudo/conteudo.php? conteudo $=56>$. Access in: 17/03/2009.

BRITTO NETO, José Gomes de. A utilização do ICMS ecológico como um instrumento de política pública para a manutenção do meio ambiente sustentável. Revista da Escola Superior da Magistratura de Sergipe, n. 6, 2004, p. 89-100.

CARRAZZA, Roque Antonio. Curso de direito constitucional tributário. 14 $4^{\mathrm{a}}$ edição, rev. ampl. e atual. São Paulo: Malheiros, 2000.

CARVALHO, Paulo de Barros. Curso de direito tributário. $18^{\mathrm{a}} \mathrm{ed}$. rev. atual. São Paulo: Saraiva, 2007.

COUTINHO, João Hélio de Farias Moraes. Instrumentos jurídicos econômicos e preservação do meio ambiente: um enfoque no ICMS Sócio-Ambiental. Revista de Informação Legislativa. Brasília: a. 39, n. 154, abr-jun 2002, p. 189-201.

FIORILLO, Celso Antonio Pacheco. Direito ambiental tributário como instrumento em defesa do direito a cidades sustentáveis no Brasil e o IPTU progressivo no tempo. Revista dos Tribunais, São Paulo, 2005, p. 97-101.

GUIMARÃES, Luiz Claudio. Direito ambiental e extrafiscalidade dos impostos no direito tributário brasileiro. Revista dos Formandos em Direito Econômico da Bahia, Salvador, UFBA, v. 5, p. 345-358.

GRAN, M. G. Fiscal Incentives for Biodiversity Conservation: The ICMS Ecológico in Brazil. Available at: https://www.cbd.int/financial/ fiscalenviron/brazil-fiscalicms-iied.pdf. Access in: 30/03/2014.

GRAU, Eros Roberto. Icms: análise da constitucionalidade da vinculação da receita tributária prevista na lei 6556 de 1989. Revista de Direito Tributário, São Paulo, Malheiros, v. 68, 1995, p. 71-75.

HARADA, Kiyoshi. Critério de rateio do fundo de participação dos municípios. Repertório de Jurisprudência Tributário, Constitucional e Administrativo, São Paulo, v. 1, n. 10, maio/2007, p. 425-427.

HARDT, Carlos et al. Gestão metropolitana: relação com a população 
e com a qualidade hidrica. ABEP, 2008. Available on: <http://www. abep.nepo.unicamp.br/encontro2008/docsPDF/ABEP2008_1735.pdf> Access in 01/02/2014.

LOUREIRO, Wilson. ICMS Ecológico: a consolidação de uma experiência brasileira de incentivo a Conservação da Biodiversidade. Disponível em: <http://www.ambientebrasil.com.br/composer. php3?base $=. /$ snuc/index.html\&conteudo=./snuc/artigos/icms.html. $>$ Acesso em 07/03/2014.

LOUREIRO, Wilson et. al.. The Ecological Value-Added Tax: Municipal Responses in Parana and Minas Gerais. Available at: http://www. icmsecologico.org.br/images/artigos/a024.pdf. Access on 01/03/2014.

MACHADO, Hugo de Brito. Curso de Direito Tributário. $14^{\mathrm{a}}$ ed. São Paulo: Malheiros, 1998.

MACHADO, Paulo Affonso Leme. Direito Ambiental Brasileiro. $11^{\mathrm{a}}$ ed. São Paulo: Malheiros, 2003.

MODÉ, Fernando Magalhães. Tributação ambiental: a função do tributo na proteção do meio ambiente. Curitiba: Juruá, 2003.

MORAES, Alexandre de. Constituição do Brasil interpretada e legislação constitucional. 7. ed. atual. até a EC n55/07. São Paulo: Atlas, 2007.

NUSDEO, Fabio. Curso de economia: introdução ao direito econômico. 4. ed. rev. e atual. São Paulo: Editora Revista dos Tribunais, 2005.

OLIVEIRA, José Marcos Domingues de. Meio ambiente, tributação e vinculação de impostos. Revista da Faculdade de Direito da Universidade do Rio de Janeiro, Rio de Janeiro, UERJ, v. 1, n. 1, p. 84-91, 1993.

- Direito tributário e meio ambiente: proporcionalidade, tipicidade aberta, afetação da receita. Rio de Janeiro: Renovar, 1995. Forense, 2007.

. Direito tributário e meio ambiente. 3. ed. Rio de Janeiro:

PERALTA MONTERO, Carlos E. Extrafiscalidade e meio ambiente: o tributo como instrumento de proteção ambiental. Reflexões sobre a tributação ambiental no Brasil e na Costa Rica. 2011 (tese de doutorado) Universidade Estadual do Rio de Janeiro, Rio de Janeiro.

SCAFF, Fernando Facury; TUPIASSU, Lise Vieira da Costa. Tributação e políticas públicas: o ICMS ecológico. Revista de Direito Ambiental, São Paulo, Revista dos Tribunais, n. 38, abr-jun, 2005, p. 99-120.

SEBASTIÃO, Simone Martins. Tributo ambiental. $1^{\mathrm{a}}$. ed., $2^{\mathrm{a}}$. tir., Curitiba: Juruá, 2007. 
SECRETARIA DO MEIO AMBENTE DO ESTADO DE SÃO PAULO. ICMS Ecológico. Available at: http://www.ambiente.sp.gov.br/cpla/ icms-ecologico/. Access in 19/03/2014.

THE NATURE CONSERVANCY. Ecological ICMS: history and perspectives. Available at: http://www.icmsecologico.org.br/index. php?option $=$ com_content\&view $=$ article \&id=74\&Itemid=77. Access in $28 / 02 / 2014$.

TORRES, Heleno Taveira. et. al. Direito tributário ambiental. São Paulo: Malheiros, 2005.

TREMEL, Rosângela; PEREIRA, Patrick da Luz. ICMS ecológico: a materialização do princípio do protetor-recebedor, Revista Jurídica Consulex, Brasília, n. 198, abril/2005, p. 49-51.

UHLMANN, V. O.; ROSSATO, M. V.; PFITSCHER, E. D., Conhecimento dos gestores públicos sobre o instrumento de política pública ICMS ecológico nos municípios da quarta colônia de imigração italiana do RS, Enfoque: Reflexão Contábil UEM - Paraná, n. 29, v. 2, 2010, p. 83-102. Available at: http://periodicos.uem.br/ojs/index.php/ Enfoque/article/view/11396/6236. Access in 01/03/2014.

ZEOLA, Senise Freire Chacha. ICMS - instrumento de proteção e conservação do meio ambiente. Revista de Direito e Política, v. 8., janmar/2006, p. 55-78. 